$\mathbf{5 0}: 316$

第 54 回日本老年医学会学術集会記録

〈パネルディスカッション $1:$ フィールド医学からみた地域在住高齢者の健康〉

\title{
2. 機能性健康障害の関連因子〜血管壁硬化と身体機能を中心として〜
}

\author{
宮野伊知郎
}

Key words : 血管壁硬化, 身体機能, 日常生活動作, 地域在住高齢者

（日老医誌 $2013 ； 50 ： 316-318$ )

\section{はじめに}

高齢者における生活機能障害の要因として, 運動機能 の低下，認知機能の低下，うつ・閉じこもりなど多くの 要因が知られている. 最近の研究では, これらの要因と 動脈硬化の関連が報告されている．血管壁硬化は加齢と ともに立進し, 心血管疾患発症のリスクとなる。また,

下肢の運動機能やバランス能力も加齢とともに次第に低 下し，進行すると歩行・階段昇降などの日常生活動作に 支障をきたすようになる，これらの加齢による変化は個 人差が大きく，日常生活が自立している高齢者において も血管壁硬化抒よび身体機能の程度は個人により様々で ある．今回，高齢者における血管壁硬化が生命予後に及 ぼす影響について，さらには血管壁硬化と身体機能が生 命予後㧍よび日常生活動作 (Activities of Daily Living: ADL）の悪化に及ぼす影響について検討した，地域在 住高齢者を対象としたコホート調査の結果を紹介する.

\section{地域在住高齢者における血管壁硬化と 生命予後との関連"}

対象は高知県香美市香北地区（旧香北町）在住の 65 歳以上の高齢者 559 人. 健診受診時に高血圧, 糖尿病,

脂質異常症，心血管疾患等の既往の有無について問診に て聴取した。また，血圧測定，血液生化学検査の他，血 管壁硬化の指標である脈波伝播速度（brachial-ankle pulse wave velocity:baPWV) の測定を行った。心房細 動, 閉塞性動脈硬化症の既往, 足関節上腕血圧比 (Ankle Brachial Index） 0.9 未満の対象者を除外した 530 人（男 性 207 人, 女性 323 人, 平均年齢 76 歳）を調査対象と

The association between arterial stiffness and functional impairment

Ichiro Miyano：高知大学医学部予防医学 - 地域医療学

(公衆衛生学)
し, 3 年間の生死および死亡原因について追跡調査を 行った.

調查開始時の baPWV の平均值は男性 $18.81 \pm 4.01 \mathrm{~m} /$ $\mathrm{sec}$, 女性 $18.97 \pm 3.92 \mathrm{~m} / \mathrm{sec}$ であり, 男女差は認めなかっ た $(\mathrm{p}=0.647)$. baPWV の中央值にて対象者を 2 群に分 類し, $18.675 \mathrm{~m} / \mathrm{sec}$ 未満を low baPWV 群 $(\mathrm{n}=265)$, $18.675 \mathrm{~m} / \mathrm{sec}$ 以上を high baPWV 群 $(\mathrm{n}=265)$ とした. high baPWV 群は low baPWV 群に比し, 高齢であり $(77.7 \pm 5.5$ vs. $75.1 \pm 5.4, \mathrm{p}<0.001)$, 高血圧治療中の対 象者が多く $(50.2 \%$ vs. $35.5 \%, \mathrm{p}=0.001)$, 収縮期血圧 $(154.4 \pm 21.8$ vs. $138.9 \pm 26.4, \mathrm{p}<0.001)$ ，拡張期 血圧 $(85.5 \pm 11.5$ vs. $77.7 \pm 10.8, \mathrm{p}<0.001)$ ，脈拍 $(76.3 \pm 12.7$ vs. $70.8 \pm 11.7, \mathrm{p}<0.001)$ が高值であった.

3 年間の追跡期間中の死亡者は 30 人，そのうち心血 管死亡は 10 人であった，総死亡の頻度は high baPWV 群 (22 名, $8.3 \%$ ) は, low baPWV 群 (8名, $3.0 \%$ ) に 比し有意に高值であった $(\mathrm{p}=0.013)$ 。血管死亡の頻 度も同様に, high baPWV 群 (10名, 3.8\%) は, low baPWV 群 (1 名, $0.4 \%)$ に比し有意に高值であった $(\mathrm{p}=$ 0.011). 図1に Kaplan-Meier curveを示す. Cox 比例八 ザードモデルによる検討では, 年齢, 性, 収縮期血圧で 調整後も baPWV 高值は総死亡 (ハザード比 $=2.98,95 \%$ 信頼区間 $=1.25 \sim 7.07)$ および心血管死亡（ハザード比 $=$ 10.01，95\% 信頼区間 $=1.21 ８ 2.49 ）$ と有意な関連を認 めた. ROC 解析を用いた検討により, 総死亡のカット オフ值は $19.63 \mathrm{~m} / \mathrm{sec}$ (感度 $73 \%$, 特異度 $63 \%$ ), 心血 管死亡のカットオフ值も同様に $19.63 \mathrm{~m} / \mathrm{sec}$ (感度 $91 \%$, 特異度 $62 \%$ ）であった。

\section{血管壁硬化および身体機能と 基本的日常生活動作の悪化との関連}

対象は同じく高知県香美市香北地区（旧香北町）在住 の 65 歳以上の高齢者のうち, 調查開始時の基本的 $\mathrm{ADL}$ 

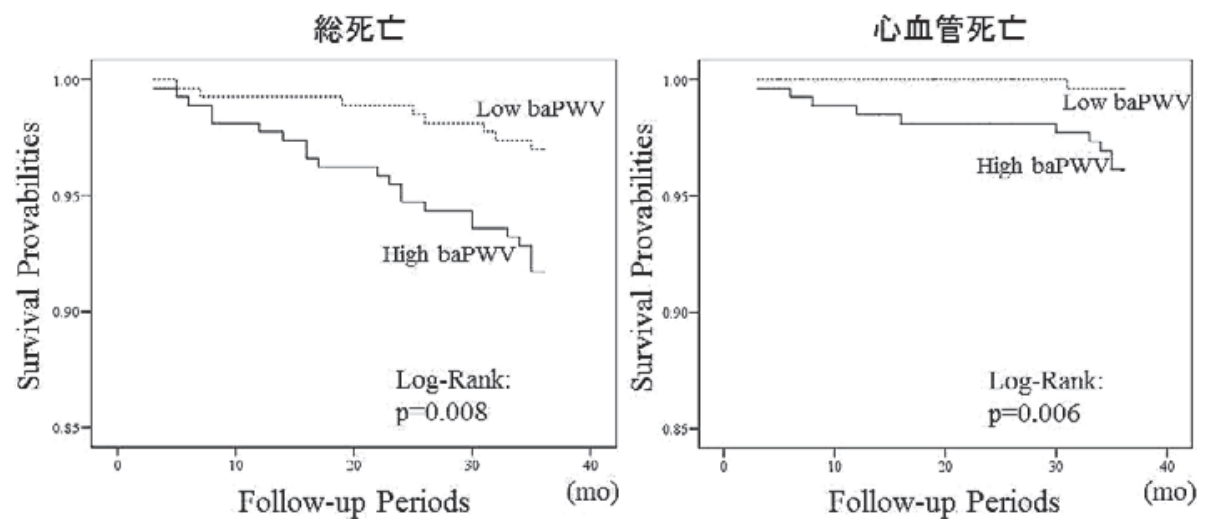

図 1 baPWV と 3 年後の生命予後 : Kaplan-Meier curve（文献 1)

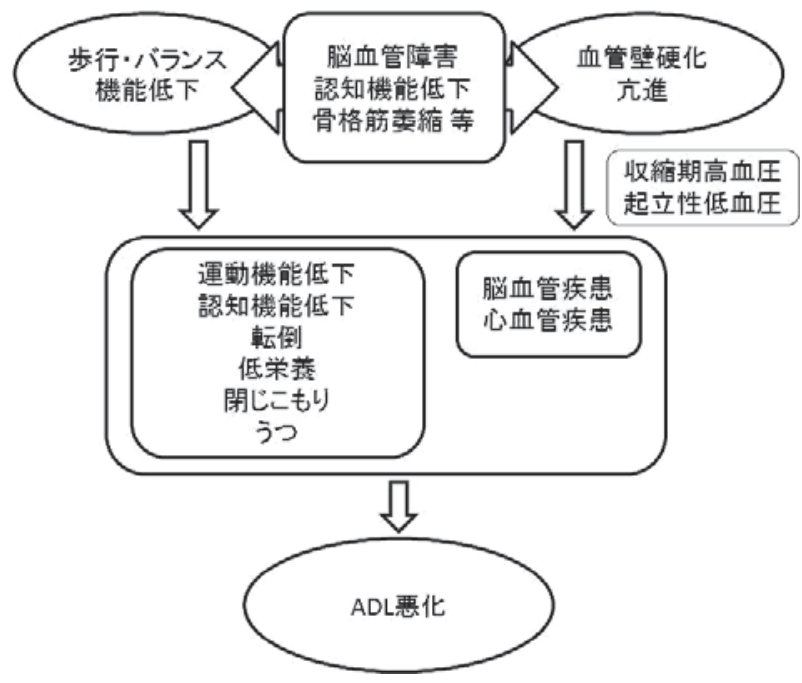

図 2 血管壁硬化および歩行・バランス機能と ADL 悪 化との関連

が自立していた 450 人（男性 181 人，女性 269 人，平均 年齢 77 歳). baPWV に加え, 歩行・バランス機能の指 標であり ADL 悪化と関連することが知られている2 Timed Up and Go Test（TUG）を実施した。調査開始 から 3 年間の生死および基本的 ADL について追跡調查 を行った，基本的 ADL は歩行，階段昇降，食事，更衣， 排泄，入浴，整容の 7 項目からなり，それぞれ $0 \sim 3$ 点 (3 点が自立), 合計 21 点満点で評価した．基本的 ADL は 20 点以上を基本的 ADL 自立と定義し, 調査開始時 は対象者全員が 20 点以上であった. 3 年間の観察期間 中, 基本的 $\mathrm{ADL}$ が 19 点以下となった対象者を基本的 ADL 悪化と定義した.

追跡可能であった 437 人のうち, 3 年間の死亡は 28 人（6.4\%）に認めた。生存し基本的 $\mathrm{ADL}$ 悪化を認めた のは 58 人 (13.3\%), 基本的 ADL 自立は 351 人 (80.3\%)
であった．対象者を baPWV の中央值で 2 群に分類し比 較検討した結果，総死亡の頻度は high baPWV 群 (21 人， $9.3 \% ） は$, low baPWV 群（7人， $3.1 \% ） に$ に比し有 意に高值であった（ $\mathrm{p}=0.010 ）$ ．基本的 ADL 悪化の頻度 も同様に, high baPWV 群 (47 人, $23.0 \%$ ) は, low baPWV 群 $(21$ 人， $9.6 \%)$ に比し有意に高值であった $(\mathrm{p}<0.001)$. 多重ロジスティック回帰分析にて年齢, 性, 収縮期血圧 で調整後， baPWV 高值（オッズ比 $=3.20 ， 95 \%$ 信頼区 間 $=1.24 \sim 8.25 ）$ および TUG（オッズ比 $=1.11 ， 95 \%$ 信 頼区間 $=1.00 \sim 1.23 ）$ は総死亡と有意な関連を認めた. また基本的 ADL 悪化に対して baPWV 高值（オッズ 比 $=2.28,95 \%$ 信頼区間 $=1.19 \sim 4.35)$ および TUG（オッ ズ比 $=1.32,95 \%$ 信頼区間 $=1.19 \sim 1.46 ）$ は有意な関連 を認めた，さらに，TUGを男性 12 秒，女性 14 秒で 2 群に分類し, baPWV と TUG がともに高值の群は, と もに低值の群に比し基本的 ADL 悪化の頻度は高值であ り $(37.0 \%$ vs. 4.8\%), そのオッズ比は 8.1 （95\% 信頼区

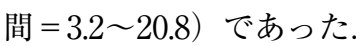

\section{おわりに}

近年，血管壁硬化の立進は無症候性脳血管障害 ${ }^{3)}$, 認 知機能障害 ${ }^{4)}$, 骨格筋萎縮5) と関連することが報告されて いる。，一方でこれらの障害は歩行機能やバランスといっ た身体機能の低下と密接な関連がある。したがって血管 壁硬化の元進と身体機能の低下の背景には一部に共通す る病態が潜在的に存在すること,さらにこの両者は直接 的あるいは間接的に ADL 悪化の要因となることが考え られる(図2)。

地域在住高齢者において血管壁硬化の評価は，生命予 後の悪化だけでなく ADL 覀化を予測するうえで有用で あることが示唆された，さらに，血管壁硬化を身体機能 の評価と併用することにより，ADL 悪化の予測におい 
てその有用性が増すことが示唆された.

\section{文献}

1) Miyano I, Nishinaga M, Takata J, Shimizu Y, Okumiya K, Matsubayashi K, et al.: Association between brachialankle pulse wave velocity and 3-year mortality in community-dwelling older adults. Hypertens Res 2010; 33: 678-682.

2) Okumiya K, Matsubayashi K, Nakamura T, Fujisawa M, Osaki Y, Doi Y, et al:: The timed “Up \& Go" test and manual button score are useful predictors of functional decline in basic and instrumental ADL in communitydwelling older people. J Am Geriatr Soc 1999; 47: 497498.

3) Kim DH, Kim J, Kim JM, Lee AY: Increased brachial- ankle pulse wave velocity is independently associated with risk of cerebral ischemic small vessel disease in elderly hypertensive patients. Clinical Neurology and Neurosurgery 2008; 110: 599-604.

4) Fujiwara $\mathrm{Y}$, Chaves $\mathrm{PH}$, Takahashi R, Amano H, Yoshida H, Kumagai S, et al.: Arterial pulse wave velocity as a marker of poor cognitive function in an elderly community-dwelling population. J Gerontol A Biol Sci Med Sci 2005; 60: 607-612.

5) Abbatecola AM, Chiodini P, Gallo C, Lakatta E, Sutton-Tyrrell K, Tylavsky FA, et al.; for the Health $\mathrm{ABC}$ study: Pulse wave velocity is associated with muscle mass decline: Health ABC study. Age 2012; 34: 469478. 